Research Article

\title{
Economic Feasibility for Recycling of Waste Crystalline Silicon Photovoltaic Modules
}

\author{
Idiano D’Adamo, ${ }^{1}$ Michela Miliacca, ${ }^{2}$ and Paolo Rosa $^{3}$ \\ ${ }^{1}$ Department of Industrial and Information Engineering and Economics, University of L'Aquila, Via G. Gronchi 18, \\ 67100 L'Aquila, Italy \\ ${ }^{2}$ Department of Enterprise Engineering, University of Rome Tor Vergata, Via del Politecnico 1, 00133 Rome, Italy \\ ${ }^{3}$ Department of Management, Economics and Industrial Engineering, Politecnico di Milano, Piazza Leonardo da Vinci 32, 20133 \\ Milano, Italy \\ Correspondence should be addressed to Idiano D’Adamo; idiano.dadamo@univaq.it
}

Received 3 April 2017; Accepted 18 May 2017; Published 27 June 2017

Academic Editor: Yanfa Yan

Copyright (c) 2017 Idiano D’Adamo et al. This is an open access article distributed under the Creative Commons Attribution License, which permits unrestricted use, distribution, and reproduction in any medium, provided the original work is properly cited.

\begin{abstract}
Cumulative photovoltaic (PV) power installed in 2016 was equal to $305 \mathrm{GW}$. Five countries (China, Japan, Germany, the USA, and Italy) shared about $70 \%$ of the global power. End-of-life (EoL) management of waste PV modules requires alternative strategies than landfill, and recycling is a valid option. Technological solutions are already available in the market and environmental benefits are highlighted by the literature, while economic advantages are not well defined. The aim of this paper is investigating the financial feasibility of crystalline silicon ( $\mathrm{Si}$ ) PV module-recycling processes. Two well-known indicators are proposed for a reference 2000 tons plant: net present value (NPV) and discounted payback period (DPBT). NPV/size is equal to $-0.84 € / \mathrm{kg}$ in a baseline scenario. Furthermore, a sensitivity analysis is conducted, in order to improve the solidity of the obtained results. $\mathrm{NPV} /$ size varies from $-1.19 € / \mathrm{kg}$ to $-0.50 € / \mathrm{kg}$. The absence of valuable materials plays a key role, and process costs are the main critical variables.
\end{abstract}

\section{Introduction}

Global warming pushed the energy sector towards lowcarbon energy resources, and PV sources got a key role in this transition [1, 2]. The global annual PV power capacity installed was equal to $76.1 \mathrm{GW}$ in 2016 , with a net increase of $49 \%$ than 2015 (about $51.2 \mathrm{GW}$ ) according to data provided by Solar Power Europe. Reliable predictions on volumes, as well as composition, of future waste streams defined as the EoL management of solar panels are relevant topics in the literature [3,4], supporting the development of circular economies [5].

Losses of precious and scarce metals (e.g., silver, gallium, indium, and germanium), conventional materials (e.g., aluminum and glass), and the leaching of hazardous substances (e.g., lead and cadmium) are defined as the most important environmental issues linked to the incorrect disposal of waste PV panels [6, 7]. An adequate EoL management can assure the availability of secondary materials, proposing a cost efficient recovery of available resources [8]. The recent decision taken by the EU commission to include PV panels into the new Waste Electrical and Electronic Equipment (WEEE) directive follows this logic. However, potential revenues from $\mathrm{PV}$ panels recycling are lower than the ones coming from other e-wastes [9].

Among the different PV panel technologies, crystalline $\mathrm{Si}$ modules represent $85-90 \%$ of the market (data provided by the International Energy Agency). The recycling of PV modules is able to supply $>88,000$ and $>207,000$ tpa of silicon by 2040 and 2050, respectively [10]. Global warming potential (GWP) produced by recycling of 1 ton of Si PV panels is equal to $370 \mathrm{kgCO}_{2}$ eq [11], saving approximately $800-$ $1200 \mathrm{kgCO}_{2}$ eq in case of a module $100 \%$ manufactured from primary materials [12]. Hence, the recycling scenario has less environmental impact in comparison with the landfilling one [13]. 
Basically, PV panel recycling processes are composed by three macrosteps: (i) mechanical, chemical, or thermal delamination; (ii) chemical decoating; and (iii) chemical extraction/refining [14]. The recycling process of crystalline technology requires the pyrolysis at about $500^{\circ} \mathrm{C}$ for the recovery of crystalline silicon wafers from the modules and a chemical etching for the removal of metal coatings, antireflective coatings, and diffusion layers [15].

A review on recycling of solar PV modules has defined their economic viability as still unfavorable, and an efficient collection network is a relevant prerequisite [16]. The attention of companies is more focused on thin-film modules recycling, guaranteeing a higher profit thanks to the presence of precious materials [17]. Contrarily, Si-based panels are poor of valuable materials, and their recycling cost is always higher than the landfilling one, making recycling an unfavorable economic option [18]. Furthermore, a closed-loop supply chain-planning model for a PV system manufacturer defines that an internal and external recycling is the best solution when thin-film and crystalline technologies are treated, respectively [19].

The profitability of plants treating only waste PV modules is guaranteed only by managing great amounts of ewastes, at least 20,000 tons/year [20]. This size is linked also to an integrated automatic approach viable for different PV technologies [21]. Some interesting economic models are proposed in the literature $[17,20]$, and discounted cash flow (DCF) analysis is used for evaluating the financial feasibility [22]. Consequently, the economic side is still not well explored in the literature, and this paper tries to cover this gap.

The paper is organised as follows. Section 2 proposes the methodology used in this paper, and an economic model is defined for evaluating the profitability of a recovery center treating crystalline Si PV modules. Results are proposed in terms of NPV and DPBT in Section 3, and a sensitivity analysis is conducted in Section 4. Finally, Section 5 presents some concluding remarks.

\section{Methodology}

DCF is a valuation method used for estimating the profitability of a project. The calculation of cash flows is based on the incremental approach, and an adequate opportunity cost is used for aggregating them. This method considers only cash inflows and outflows. NPV and DPBT are two financial indicators typically used. The first one is defined as the sum of present values of individual cash flows, and the second one represents the number of years needed to balance cumulative discounted cash flows and the initial investment $[23,24]$.

Cash inflows are given by the amount of recovered materials multiplied by three other variables: recycling rate, material market price, and material purity level [20]. Furthermore, an additional saving can be linked to the amount of avoided conferred costs when PV manufacturers are also recyclers [25]. The price of recycled materials is chosen from the main websites focused on raw material exchanges, considering January 2016-January 2017 as the reference period [26].
Cash outflows are characterised by a low percentage weight of investment costs. In this work, the entire investment cost is covered by third-party funds. Relevant items are originated by the PV modules process and collection. The first one is basically the main cost [22], but there is a significant increase of collection cost when a great area of reference is analyzed [20]. Other materials that cannot be directly recycled are supposed to be adequately managed, with related conferred costs (e.g., plastics).

The proportion between installed power and corresponding mass of produced wastes is fixed in $1 \mathrm{MW}=75$ tons [20]. This work considers a reference 2000 tons recycling plant. To this amount of waste, an installed power of $26.7 \mathrm{MW}$ is associated. The plant useful life is estimated in 10 years, and the opportunity cost is fixed equal to 5\% [22]. The economic model used in this work is described as follows:

$$
\begin{aligned}
& \mathrm{NPV}=\mathrm{DCI}-\mathrm{DCO} \text {, } \\
& \sum_{t=0}^{\mathrm{DPBT}} \frac{\left(\mathrm{CI}_{t}-\mathrm{CO}_{t}\right)}{(1+r)^{t}}=0 \text {, } \\
& \begin{array}{r}
\mathrm{DCI}=\sum_{t=1}^{N} \begin{array}{c}
\left(m_{\mathrm{Al}}^{\mathrm{m}} * y_{\mathrm{Al}} * \mathrm{pl}_{\mathrm{Al}} * \mathrm{pr}_{\mathrm{Al}} * S\right. \\
+m_{\mathrm{Si}}^{\mathrm{m}} * y_{\mathrm{Si}} * \mathrm{pl}_{\mathrm{Si}} * \mathrm{pr}_{\mathrm{Si}} * S
\end{array}
\end{array} \\
& +m_{\mathrm{Cu}}^{\mathrm{m}} * y_{\mathrm{Cu}} * \mathrm{pl}_{\mathrm{Cu}} * \mathrm{pr}_{\mathrm{Cu}} * S \\
& \frac{\left.+m_{\text {glass }}^{\mathrm{m}} * y_{\text {glass }} * \mathrm{pl}_{\text {glass }} * \mathrm{pr}_{\text {glass }} * S\right)}{(1+r)^{t}} \text {, } \\
& \mathrm{DCO}=\sum_{t=0}^{N_{\mathrm{debt}^{-1}}} \frac{\left(\left(C_{\mathrm{inv}}^{\mathrm{u}} * S\right) / N_{\mathrm{debt}}+\left(C_{\mathrm{inv}}^{\mathrm{u}} * S-C_{\mathrm{lcs}, \mathrm{t}}\right) * r_{\mathrm{d}}\right)}{(1+r)^{t}} \\
& +\sum_{t=1}^{N}\left(C_{\mathrm{p}}^{\mathrm{u}} * S+C_{\mathrm{c}}^{\mathrm{u}} * S\right. \\
& \frac{\left.+m_{\text {plastics }}^{\mathrm{m}} * C_{\mathrm{plastics, \textrm {t }}}^{\mathrm{u}} * S+\mathrm{ebt}_{\mathrm{t}} * C_{\mathrm{tax}}^{\mathrm{u}}\right)}{(1+r)^{t}},
\end{aligned}
$$

where DCI = discounted cash inflows, DCO = discounted cash outflows, $\mathrm{CI}=$ cash inflows, $\mathrm{CO}=$ cash outflows, $t=$ time period, $\mathrm{Al}=$ aluminum, $\mathrm{Si}=$ silicon, $\mathrm{Cu}=$ copper, $\mathrm{C}_{\mathrm{lcs}}=$ loan capital share cost, and ebt $=$ earnings before taxes . Other input values are proposed in Table 1.

\section{Results}

The reduction in emissions is equal to $727 \mathrm{gCO}_{2} \mathrm{eq} / \mathrm{kWh}$ using a PV system alternatively to fossil sources or $21 \mathrm{tCO}_{2} \mathrm{eq}$ for $\mathrm{kW}$ installed during 20 years [27]. In addition, the recycling of waste $\mathrm{PV}$ modules reduces the emissions using recovered materials alternatively to primary ones (see Section 1). The profitability of PV systems is verified in both developed and developing markets [27, 28]. Instead, the evaluation concerning the economic opportunity of recovery of PV modules is investigated in this paper. Table 2 proposes the business plan required to define the investment's profitability.

DCF analysis is used for evaluating the financial feasibility of Si PV recycling plants. Results obtained in Table 2 
TABLE 1: Input values [20, 22]

\begin{tabular}{|c|c|c|}
\hline Acronym & Variable & Value \\
\hline$C_{\mathrm{c}}^{\mathrm{u}}$ & Unitary collection cost & $210 € /$ ton \\
\hline$C_{\mathrm{cm}}^{\mathrm{u}}$ & Unitary conferred materials cost & $90 € /$ ton \\
\hline$C_{\text {inv }}^{\mathrm{u}}$ & Unitary investment cost & $270 € /$ ton \\
\hline$C_{\mathrm{p}}^{\mathrm{u}}$ & Unitary process cost & $320 € /$ ton \\
\hline$C_{\operatorname{tax}}^{\mathrm{u}}$ & Unitary taxes cost & $36 \%$ \\
\hline $\inf$ & Rate of inflation & $2 \%$ \\
\hline$m_{\mathrm{m}}^{\mathrm{m}}$ & Mass/module of conferred material ${ }^{*}$ & $128 \mathrm{~kg} /$ ton plastics \\
\hline$m_{\mathrm{rm}}^{\mathrm{m}}$ & Mass/module of recycled material* & $175 \mathrm{~kg} /$ ton $\mathrm{Al} ; 10 \mathrm{~kg} /$ ton $\mathrm{Cu} ; 29 \mathrm{~kg} /$ ton Si; $658 \mathrm{~kg} /$ ton glass \\
\hline$N$ & Lifetime of investment & $10 \mathrm{y}$ \\
\hline$N_{\text {debt }}$ & Period of loan & $10 \mathrm{y}$ \\
\hline $\mathrm{pl}_{\mathrm{rm}}$ & Purity level of recycled material & $100 \%$ \\
\hline $\mathrm{pr}_{\mathrm{rm}}$ & Price of recycled material & $1.6 € / \mathrm{kg} \mathrm{Al} ; 4.9 € / \mathrm{kg} \mathrm{Cu} ; 1.4 € / \mathrm{kg} \mathrm{Si} ; 0.1 € / \mathrm{kg}$ glass \\
\hline$r$ & Opportunity cost of capital & $5 \%$ \\
\hline$r_{\mathrm{d}}$ & Interest rate on a loan & $3 \%$ \\
\hline$S$ & Size & 2000 tons \\
\hline$y_{\mathrm{rm}}$ & Yield of recycled material & $100 \% \mathrm{Al} ; 78 \% \mathrm{Cu} ; 85 \% \mathrm{Si}$; $97 \%$ glass \\
\hline
\end{tabular}

* Materials composition in 1 ton of crystalline Si PV modules: $17.5 \% \mathrm{Al}, 65.8 \%$ glass, $2.9 \% \mathrm{Si}, 1 \% \mathrm{Cu}$, and $12.8 \%$ plastics.

TABle 2: Business plan (k€).

\begin{tabular}{lcccccccccccc}
\hline Year & 0 & 1 & 2 & 3 & 4 & 5 & 6 & 7 & 8 & 9 \\
\hline CI & 0 & 833 & 850 & 867 & 884 & 902 & 920 & 938 & 957 & 976 & 996 \\
CO & 69 & 1036 & 1055 & 1074 & 1094 & 1114 & 1134 & 1155 & 1176 & 1198 & 1187 \\
CI - CO & -69 & -203 & -205 & -207 & -209 & -212 & -214 & -217 & -219 & -222 & -191 \\
DCI - DCO & -69 & -193 & -186 & -179 & -172 & -166 & -160 & -154 & -148 & -143 & -117 \\
$\sum$ DCI - DCO & -69 & -262 & -448 & -627 & -799 & -965 & -1125 & -1279 & -1427 & -1570 & -1688 \\
\hline
\end{tabular}

define the nonprofitability of investments, given the following values assumed by the selected indicators:

(i) NPV is equal to $-1688 \mathrm{k}$.

(ii) $\mathrm{NPV} /$ size is equal to $-0.84 € / \mathrm{kg}$.

(iii) DPBT is greater than 10 years.

These values are coherent with the existing literature. $\mathrm{NPV} /$ size varies from $-1.9 € / \mathrm{kg}$ to $-4.3 € / \mathrm{kg}$, and the 1480 ton plant has a significant economic improvement than the 185 tons one [22]. This effect is highlighted also by Choi and Fthenakis, where the monthly profit ranges from -7509 $\$ /$ month to $-10,100$ \$/month [20]. Another work defines as unitary profits are equal to $-23.96 \$ /$ module [17]. Finally, the profitability is verified with a 20,000-ton plant and a monthly profit equal to $624,755 \$$ /month [20]. Furthermore, Cucchiella et al. propose values of DPBT greater than 10 years [22]. In the worst scenario, investors define the cutoff period equal to the recycling plant's useful life, with a consequent DPBT >10 defining the impossible recovery of the initial investment within this period. Figure 1 proposes the percentage distribution of both discounted cash inflows and outflows.
The amount of aluminum in crystalline Si PV modules is approximately equal to one-fifth of the total mass, but its economic value is equal to two-third of total revenues. Glass follows aluminum, characterised by a lower market value, but a higher quantity. Finally, copper is the most valuable material in crystalline modules contributing to $9 \%$ of total revenues, despite its content is equal to $1 \%$ of the total mass. The analysis of costs distribution is characterised heavily by recovery and collection processes. Together, these two items have a percentage weight greater than $90 \%$.

\section{Sensitivity Analysis}

Results are based on assumptions done on a set of input variables. The sensitivity analysis reveals the influence of changes in value of financial variables [29]. Sixteen scenarios are evaluated in this phase of the work, obtained by the variation of $\pm 20 \%$ of all the variables defined in Figure 1 (Table 3). The variations of financial indicator are proposed in Figure 2.

The unprofitability is verified in all scenarios taken into account. Minimum and maximum values are verified when the unitary process cost is increased/decreased of $20 \%$. NPV varies from $-2375 \mathrm{k} €$ to $-1001 \mathrm{k} €$. A significant change 
Discounted cash inflows

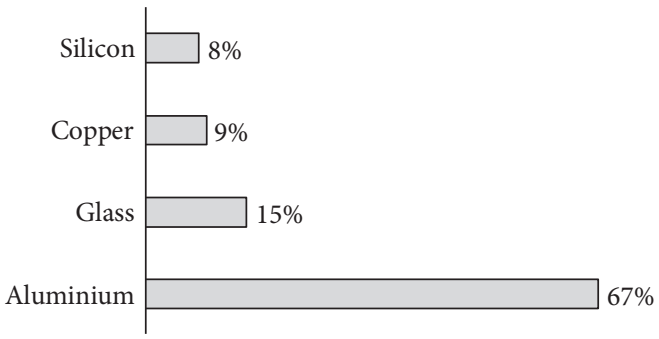

Discounted cash outflows

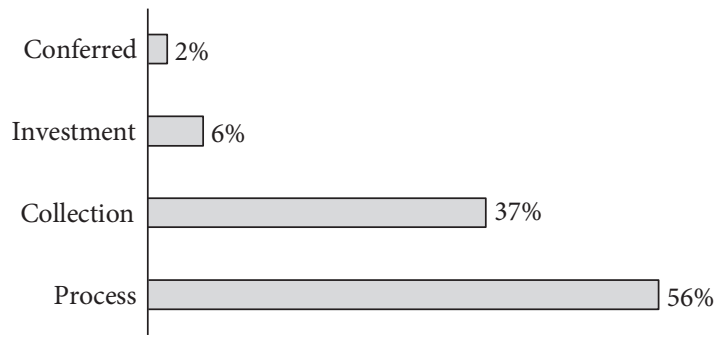

FIgURE 1: Percentage distribution of cash flows.

TABle 3: Alternative scenarios.

\begin{tabular}{lccc}
\hline Revenue items (scenarios) & Value & Cost items (scenarios) & \multicolumn{1}{c}{ Value } \\
\hline Aluminum price $+20 \%$ & $\operatorname{pr}_{\mathrm{Al}}=1.9 € / \mathrm{kg}$ & Process cost $-20 \%$ & $C_{\mathrm{p}}^{\mathrm{u}}=256 € /$ ton \\
Aluminum price $-20 \%$ & $\mathrm{pr}_{\mathrm{Al}}=1.3 € / \mathrm{kg}$ & Process cost $+20 \%$ & $C_{\mathrm{p}}^{\mathrm{u}}=384 € /$ ton \\
Glass price $+20 \%$ & $\mathrm{pr}_{\mathrm{Glass}}=0.12 € / \mathrm{kg}$ & Collection cost $-20 \%$ & $C_{\mathrm{c}}^{\mathrm{u}}=168 € /$ ton \\
Glass price $-20 \%$ & $\mathrm{pr}_{\mathrm{Glass}}=0.08 € / \mathrm{kg}$ & Collection cost $+20 \%$ & $C_{\mathrm{c}}^{\mathrm{u}}=252 € /$ ton \\
Copper price $+20 \%$ & $\mathrm{pr}_{\mathrm{Cu}}=5.9 € / \mathrm{kg}$ & Investment cost $-20 \%$ & $C_{\text {inv }}^{\mathrm{u}}=216 € /$ ton \\
Copper price $-20 \%$ & $\mathrm{pr}_{\mathrm{Cu}}=3.9 € / \mathrm{kg}$ & Investment cost $+20 \%$ & $C_{\mathrm{inv}}^{\mathrm{u}}=324 € /$ ton \\
Silicon price $+20 \%$ & $\mathrm{pr}_{\mathrm{Si}}=1.7 € / \mathrm{kg}$ & Conferred cost $-20 \%$ & $C_{\mathrm{cm}}^{\mathrm{u}}=72 € /$ ton \\
Silicon price $-20 \%$ & $\mathrm{pr}_{\mathrm{Si}}=1.1 € / \mathrm{kg}$ & Conferred cost $+20 \%$ & $C_{\mathrm{cm}}^{\mathrm{u}}=108 € /$ ton \\
\hline
\end{tabular}
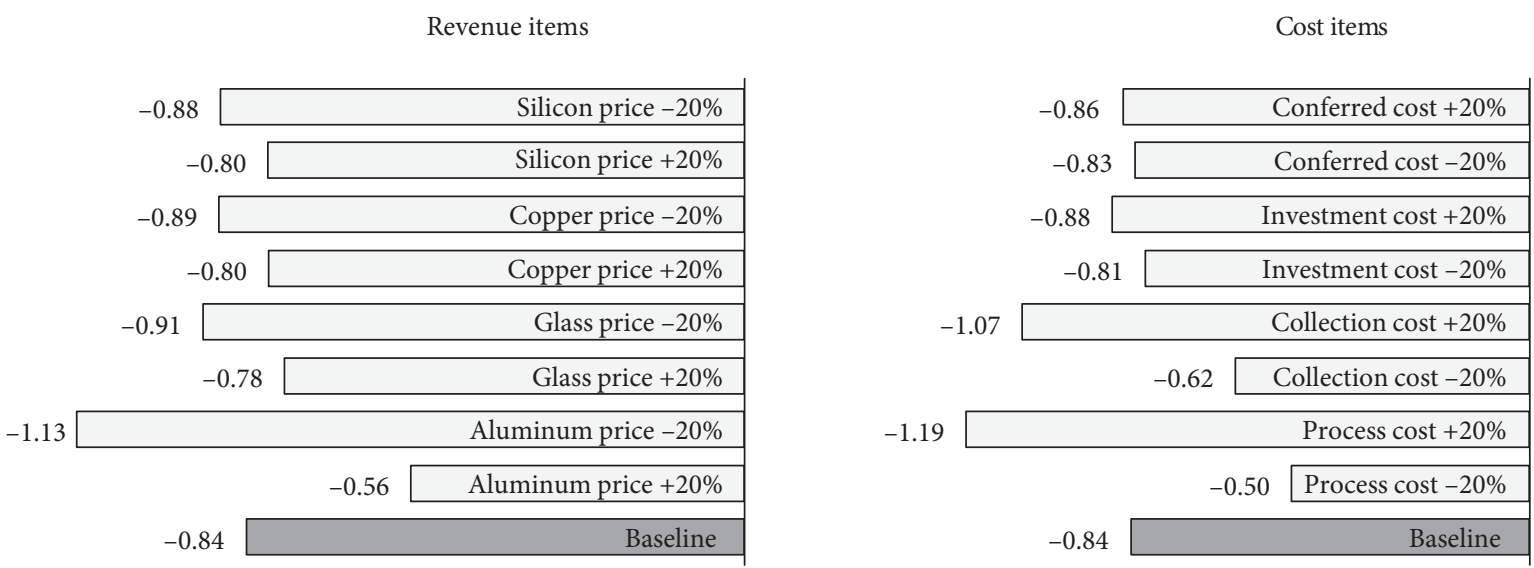

FIgURE 2: NPV/size $(€ / \mathrm{kg})$ in alternative scenarios.

is determined also by aluminum price among revenue items and by unitary collection cost among cost items. DPBT is always greater than 10 years and NPV/size ranges from $-1.19 € / \mathrm{kg}$ to $-0.50 € / \mathrm{kg}$. These results confirm the ones obtained in a baseline scenario. The unprofitability of recycling of waste crystalline Si PV modules is linked to the absence of critical and valuable materials embedded in these PV modules. Instead, thin-film technologies present valuable metals (like indium and gallium) and other interesting metals (like tellurium and selenium). However, the share of PV market (see Section 1) highlights as the amount of thin film waste $\mathrm{PV}$ modules is low.

Regardless of its role among WEEEs, recycling crystalline Si PV modules is unprofitable, and possible solutions to make a recycling plant economically profitable can be the following:

(i) The presence of thin-film modules among wastes treated.

(ii) The impact of economies of scale (especially on operative costs).

(iii) The positive role of learning economies.

(iv) Innovative processes able to reduce operative costs and increasing the purity level of recycled materials.

(v) The competitiveness of the recycled materials market. 
(vi) The recovery of PV modules in multicore plants.

\section{Conclusions}

The future of the global power sector is characterised by an impressive increase in the use of renewable sources. In this context, PV systems have a key role, able to produce both economic opportunities and environmental improvements. This paper evaluates a recycling plant treating 2000 tons of waste crystalline Si PV modules. An installed power equal to $26.7 \mathrm{MW}$ is linked to this amount of waste, allowing savings of about $560,700 \mathrm{tCO}_{2}$ eq during the lifetime of a PV system (estimated in 20 years) alternatively to fossil fuels. After this period, PV modules can be recycled, instead of being landfilled, additionally saving about $1600-2400 \mathrm{tCO}_{2}$ eq. This work proposes a quantitative approach evaluating the profitability of a PV module recovery plant. Results are coherent with the literature. The absence of valuable metals/materials produces economic losses. NPV varies from $-2375 \mathrm{k} €$ to $-1001 \mathrm{k} €(-1688 \mathrm{k} €$ in a baseline scenario), NPV/size ranges from $-1.19 € / \mathrm{kg}$ to $-0.50 € / \mathrm{kg}(-0.84 € / \mathrm{kg}$ in a baseline scenario), and DPBT is always greater than 10 years. However, the unprofitability of this project does not means that the recycling of crystalline PV modules should be discarded, given their role among WEEEs. An integration among all the typologies of PV modules is required, and the presence of valuable materials in thin-film technologies can increase the value-added recycling processes, as highlighted in the literature. However, the amount of these wastes is low and not sufficient. The construction of recycling plants with a great capacity produces economic advantages in terms of reduction of costs, but also increasing pollution levels generated by transport flows. A recovery centre treating several typologies of waste (multicore) could be the solution to these issues.

\section{Conflicts of Interest}

The authors declare that they have no conflicts of interest.

\section{References}

[1] S. Daliento, A. Chouder, P. Guerriero et al., "Monitoring, diagnosis, and power forecasting for photovoltaic fields: a review," International Journal of Photoenergy, vol. 2017, 13 pages, 2017.

[2] F. Cucchiella and I. D'Adamo, "A multicriteria analysis of photovoltaic systems: energetic, environmental, and economic assessments," International Journal of Photoenergy, vol. 2015, 8 pages, 2015 .

[3] R.-T. Chen and C.-F. Liao, "Evaluation and optimization to recycle used $\mathrm{TiO} 2$ photoelectrode for dye-sensitized solar cells," International Journal of Photoenergy, vol. 2014, 7 pages, 2014.

[4] J. Shin, J. Park, and N. Park, “A method to recycle silicon wafer from end-of-life photovoltaic module and solar panels by using recycled silicon wafers," Solar Energy Materials and Solar Cells, vol. 162, pp. 1-6, 2017.

[5] O. Malandrino, D. Sica, M. Testa, and S. Supino, "Policies and measures for sustainable management of solar panel end-oflife in Italy," Sustainability, vol. 9, p. 481, 2017.
[6] V. Monier and M. Hestin, Study on Photovoltaic Panels Supplementing the Impact Assessment for a Recast of the WEEE Directive Final Report, European Commission DG ENV, Brussels, Belgium, 2011.

[7] P. Dias, S. Javimczik, M. Benevit, and H. Veit, "Recycling WEEE: polymer characterization and pyrolysis study for waste of crystalline silicon photovoltaic modules," Waste Management, vol. 60, pp. 716-722, 2017.

[8] J. R. Peeters, D. Altamirano, W. Dewulf, and J. R. Duflou, "Forecasting the composition of emerging waste streams with sensitivity analysis: a case study for photovoltaic (PV) panels in Flanders," Resources, Conservation and Recycling, vol. 120, pp. 14-26, 2017.

[9] F. Cucchiella, I. D’Adamo, S. C. Lenny Koh, and P. Rosa, "Recycling of WEEEs: an economic assessment of present and future e-waste streams," Renewable and Sustainable Energy Reviews, vol. 51, pp. 263-272, 2015.

[10] Y. K. Yi, H. S. Kim, T. Tran, S. K. Hong, and M. J. Kim, "Recovering valuable metals from recycled photovoltaic modules," Journal of the Air \& Waste Management Association, vol. 64, pp. 797-807, 2014.

[11] C. E. L. Latunussa, F. Ardente, G. A. Blengini, and L. Mancini, "Life cycle assessment of an innovative recycling process for crystalline silicon photovoltaic panels," Solar Energy Materials and Solar Cells, vol. 156, pp. 101-111, 2016.

[12] PV Cycle, “Annual report," 2012, http://www.pvcycle.org/.

[13] B. Huang, J. Zhao, J. Chai, B. Xue, F. Zhao, and X. Wang, "Environmental influence assessment of China's multi-crystalline silicon (multi-Si) photovoltaic modules considering recycling process," Solar Energy, vol. 143, pp. 132-141, 2017.

[14] E. Klugmann-Radziemska and P. Ostrowski, "Chemical treatment of crystalline silicon solar cells as a method of recovering pure silicon from photovoltaic modules," Renewable Energy, vol. 35, pp. 1751-1759, 2010.

[15] V. M. Fthenakis, "End-of-life management and recycling of PV modules," Energy Policy, vol. 28, pp. 1051-1058, 2000.

[16] J. Tao and S. Yu, "Review on feasible recycling pathways and technologies of solar photovoltaic modules," Solar Energy Materials and Solar Cells, vol. 141, pp. 108-124, 2015.

[17] J.-K. Choi and V. Fthenakis, "Economic feasibility of recycling photovoltaic modules," Journal of Industrial Ecology, vol. 14, no. 6, pp. 947-964, 2010.

[18] C. Sener and V. Fthenakis, "Energy policy and financing options to achieve solar energy grid penetration targets: accounting for external costs," Renewable and Sustainable Energy Reviews, vol. 32, pp. 854-868, 2014.

[19] S. Kim and B. Jeong, "Closed-loop supply chain planning model for a photovoltaic system manufacturer with internal and external recycling," Sustainability, vol. 8, p. 596, 2016.

[20] J.-K. Choi and V. Fthenakis, "Crystalline silicon photovoltaic recycling planning: macro and micro perspectives," Journal of Cleaner Production, vol. 66, pp. 443-449, 2014.

[21] F. Pagnanelli, E. Moscardini, G. Granata et al., "Physical and chemical treatment of end of life panels: an integrated automatic approach viable for different photovoltaic technologies," Waste Management, vol. 59, pp. 422-431, 2017.

[22] F. Cucchiella, I. D'Adamo, and P. Rosa, "End-of-life of used photovoltaic modules: a financial analysis," Renewable and Sustainable Energy Reviews, vol. 47, pp. 552-561, 2015. 
[23] F. Cucchiella, I. D’Adamo, and P. Rosa, "Industrial photovoltaic systems: an economic analysis in non-subsidized electricity markets," Energies, vol. 8, p. 12350, 2015.

[24] A. A. Bayod-Rujula, A. Burgio, Z. Leonowicz, D. Menniti, A. Pinnarelli, and N. Sorrentino, "Recent developments of photovoltaics integrated with battery storage systems and related feed-in tariff policies: a review," International Journal of Photoenergy, vol. 2017, 12 pages, 2017.

[25] N. C. McDonald and J. M. Pearce, "Producer responsibility and recycling solar photovoltaic modules," Energy Policy, vol. 38, pp. 7041-7047, 2010.

[26] Metalprices, "Metals," 2017, https://www.metalprices.com/.

[27] F. Cucchiella, I. D’Adamo, and M. Gastaldi, "A profitability assessment of small-scale photovoltaic systems in an electricity market without subsidies," Energy Conversion and Management, vol. 129, pp. 62-74, 2016.

[28] K. L. Amani, R. Sam, and F. Zougmorè, “Competitiveness level of photovoltaic solar systems in Ouagadougou (Burkina Faso): study based on the domestic electric meters calibration," International Journal of Photoenergy, vol. 2016, 10 pages, 2016.

[29] K. Wu, H. Zhou, and J. Liu, "Optimal capacity allocation of large-scale wind-PV-battery units," International Journal of Photoenergy, vol. 2014, 13 pages, 2014. 

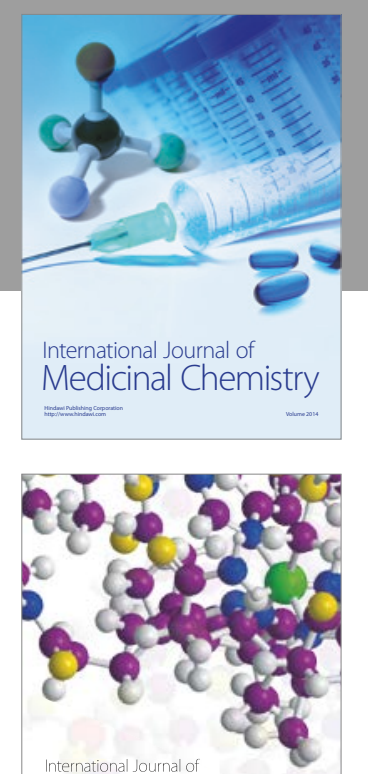

Carbohydrate Chemistry

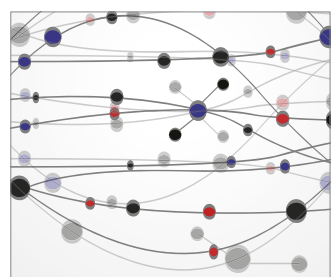

The Scientific World Journal
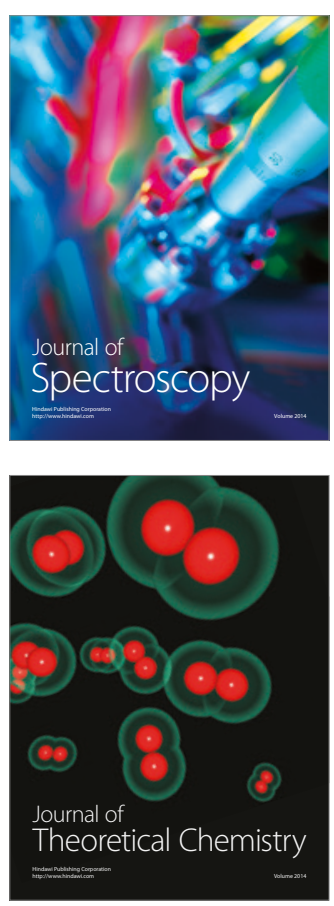
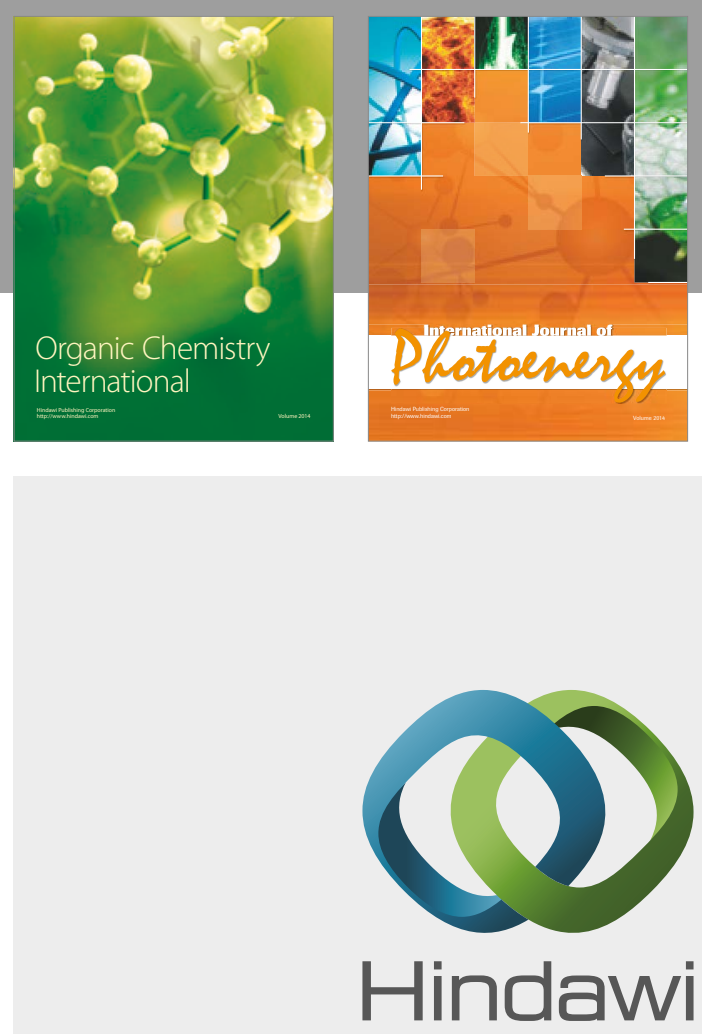

Submit your manuscripts at

https://www.hindawi.com

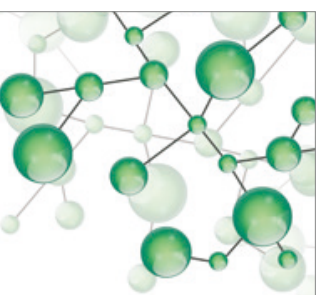

International Journal of

Inorganic Chemistry

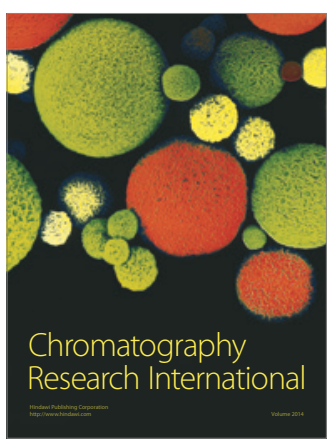

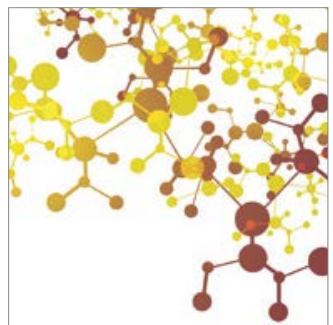

Applied Chemistry
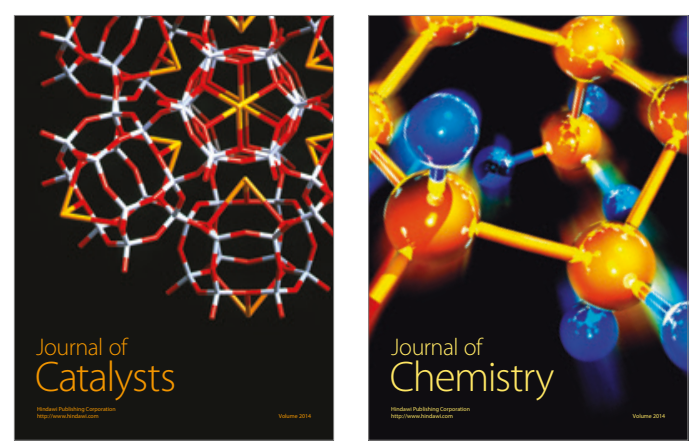
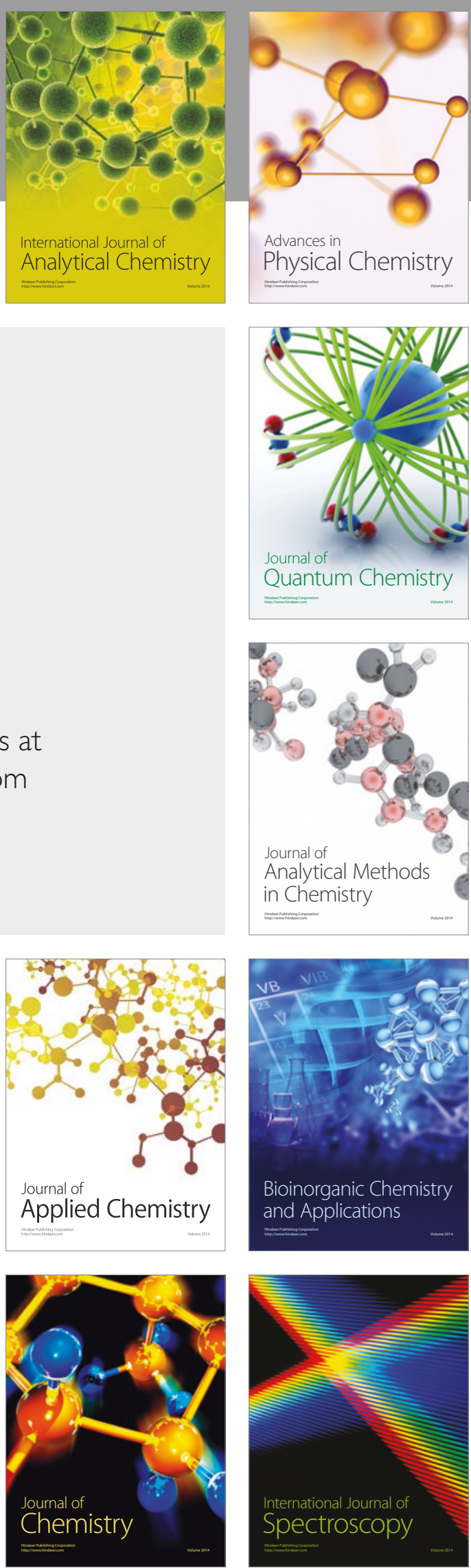